\title{
Fish Species Diversity in Headwaters Streams of Paraguay and Paraná Basins
}

\author{
Yzel Rondon Súarez ${ }^{*}$, Sabrina Bigatão Valério ${ }^{1}$, Karina Keyla Tondado ${ }^{2}$, Alexandro \\ Cezar Florentino $^{2}$, Thiago Rota Alves Felipe ${ }^{3}$, Lidiani Queli Lubas Ximenes ${ }^{2}$ and Luzia da \\ Silva Lourenço ${ }^{2}$ \\ ${ }^{1}$ UEMS - Centro Integrado de Análise e Monitoramento Ambiental; Laboratório de Ecologia; Rod. Dourados- \\ Itahum km 12; 70804-970; yzel@uems.br; Dourados - MS - Brasil. ${ }^{2}$ UFMT; Pós-graduação em Ecologia e \\ Conservação da Biodiversidade; Dourados - MS - Brasil. ${ }^{3}$ Universidade Federal de Viçosa; Pós-Graduação em \\ Biologia Animal; Viçosa - MG - Brasil
}

\begin{abstract}
The influence of spatial, temporal and environmental factors on fish species diversity in headwater streams in Paraguay and Paraná basins, Brazil was examined. A total of 4,605 individuals were sampled, distributed in 60 species. The sampled streams in Paraná basin presented a larger total species richness (42) than Paraguay streams (40). However the estimated richness was larger in Paraguay basin (53) than Paraná streams (50). The streams of Paraná basin had a greater mean species richness and evenness, while more individuals per sample were found in the Paraguay basin. Difference between the sub-basins were found in the Paraguay basin, while for the basin of Paraná, richness and evenness vary significantly between the sub-basins, but the number of individuals varied seasonally. The most important environmental factors to species diversity and abundance were altitude, water temperature, stream width and stream depth for both the basins.
\end{abstract}

Key words: Community ecology, fish diversity, streams, Paraguay Basin, Paraná Basin

\section{INTRODUCTION}

Spatio-temporal variation in the environmental characteristics as well as resource availability are among the main determinants of the species distribution (Grenouillet et al., 2002), species interaction (Zaret and Rand, 1971; Deus and Petrere Júnior, 2003) and habitat adaptations (Poff and Allan, 1995; Mérigoux et al., 2001), thus determining the diversity of fish communities. Resh et al., (1988) proposed that the two most important factors determining the structure of the lotic communities were hydrology, which affected the abiotic features and substrate. Many studies have quantified the importance of environmental features in stream fishes communities structure (eg. Bain et al., 1988; Barreto and Uieda, 1998; Martin-Smith, 1998; Taylor, 2000; Oberdorff et al., 2001, Peres-Neto, 2004). Tonn et al., (1990) studying fishes communities in Canada and Europe lakes, proposed a model in which biogeographic aspects interacted with the local factors and biotic interactions to determine the local fishes species composition. Jackson et al., (2001) suggested that the occurrence of certain species in a locale was the result of the interaction of biogeographic factors, which define the

\footnotetext{
${ }^{*}$ Author for correspondence
} 
colonization opportunities and environmental characteristics.

Many studies have examined the importance of the local versus regional factors to determine the lotic fishes community structure (eg. Belliard et al., 1997; Angermeier and Winston, 1998). Lamouroux et al., (2002) compared the influence of hydrological features on stream fishes community organization of France and United States of America (Virginia) and concluded that, despite continental differences, certain fish species traits showed a clear convergent pattern, suggesting the existence of a key factor driving the evolution of these communities.

The Pantanal is a tectonic basin originated during the Andes formation, with its peak in Mioceno (Godoi-Filho, 1986). Upper Paraguay and upper Paraná basins present an interface area, where countless headwater streams form the main rivers of both basins. Despite the short distance between them, sometimes only about $15 \mathrm{~km}$, and with similar climate, they have present differences in relief resulting from the formation of the Paraguay basin, and their fish communities are isolated.

The present study examined the following questions:

1) Did the headwater streams of the Paraguay and Paraná basins show differences in the diversity and abundance of their fishes communities?

2) Were there significant seasonal and spatial significant variations in diversity and fish species abundance in these streams? Which variation source was the most important?

3) Were the environmental factors important to determine diversity and species abundance in these streams?

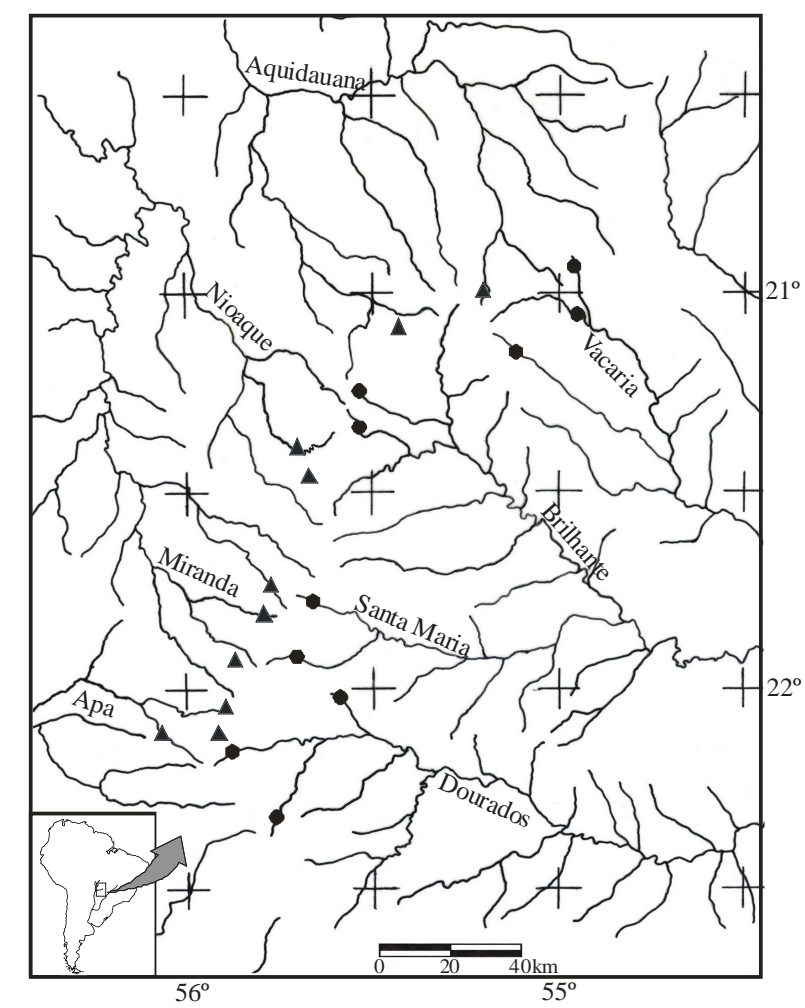

Figure 1 - Location of sampled streams in Paraguay $(\boldsymbol{\Delta})$ and Paraná $(\bullet)$ basins

\section{MATERIAL AND METHODS}

The studied region is located in a $200 \mathrm{~km}$ extension of interface between the Paraguay/Paraná basins, between the latitudes S20 $54^{\prime}$ to $22^{\circ} 18^{\prime}$ and longitudes W54 56 to $56^{\circ} 05^{\prime}$. Samples were collected bimonthly in 10 streams of each basin (Fig. 1), from January to November 2004, totaling 60 samples per basin. In each basin, streams from four sub-basins were selected: The Apa and Miranda sub-basins in the Paraguay catchments have uneven relief, with countless waterfalls higher than $30 \mathrm{~m}$ which act as barriers to fish migration within the basin. 
The widths of the streams selected for the sampling varied from 0.6 to $7 \mathrm{~m}$, their depth from 0.11 to $1.75 \mathrm{~m}$, water velocity from 0.056 to 1.90 $\mathrm{m} / \mathrm{s}$ and altitude from 264 to $641 \mathrm{~m}$. The streams are relatively well preserved, with most of the natural riparian vegetation remaining and a small human population. The samples were taken during the daylight with a rectangular sieve $1.2 \times 0.8 \mathrm{~m}$, with $2 \mathrm{~mm}$ mesh size and standardized effort $(20$ throws) at each site, with approximately 50-mlong hauls. This method was selected because of the difficulty in using electroshocking in streams with low water conductivity, difficult to access, and with variable turbidity that made it difficult to see the fish.

Specimens were fixed in formalin $(10 \%)$ and preserved in alcohol (70\%) for counting. They were identified using Pantanal fish identification key (Britski et al. 1999), as well as specific identification keys for each taxonomic groups and comparison with paratypes of the Zoology Museum of Universidade de São Paulo (MZUSP) and of the National Museum (MNRJ). For each sample a set of environmental data was obtained: $\mathrm{pH}$, conductivity $\left(\mathrm{mS} / \mathrm{cm}^{-1}\right)$, water temperature $\left({ }^{\circ} \mathrm{C}\right)$ and dissolved oxygen (\% saturation), using a YSI model 556 field multi-probe. Turbidity was obtained with a portable turbidity meter. Stream depth $(\mathrm{m})$ was obtained at ten locations on each transect (50m-long), with a graduated wooden stick. Water velocity $(\mathrm{m} / \mathrm{s})$ was measured three to five times in different parts of the transect, using a float method. Stream width $(\mathrm{m})$ was measured with a measuring tape, and altitude $(\mathrm{m})$ using the altimeter of a GPS.

Richness, evenness and number of individuals collected were compared between the two basins (Paraguay and Paraná), using Student "t" test. When the normality and variance homogeneity were violated (even after data transformation), the Mann-Whitney test was used. Total species richness and Confidence Interval (CI) for each basin were estimated using a Jackknife procedure (Heltshe and Forrester, 1983). The importance of seasonal and spatial variation in species diversity and abundance was assessed by the Analyses of Variance (ANOVA). The sub-basins, month of the sampling were explanatory variables (categories) and richness, evenness and numbers of individuals collected were response variables. A multiple linear regression was used to determine the importance of environmental factors in structuring fish communities.

\section{RESULTS}

A total of 4,605 individuals of 60 species were collected. In the Paraguay basin, 40 species were identified; in Paraná basin, 42 species were identified. The result of the jackknife procedure estimated 53 fishes species in the Paraguay basin $\left(\mathrm{CI}_{0.05}=52\right.$ to 54$)$ and $50\left(\mathrm{CI}_{0.05}=49\right.$ to 51$)$ in the Paraná basin. The Paraná basin showed a higher mean richness $(\mathrm{t}=3.288 ; \mathrm{gl}=118 ; \mathrm{P}=0.001)$. The number of the individuals collected was significantly larger in Paraguay basin $(\mathrm{t}=2.373$; $\mathrm{gl}=118 ; \mathrm{P}=0.019$ ) and evenness was significantly higher in the Paraná basin $(U=1347 ; Z=2.377$; $\mathrm{P}=0.017$ ) (Fig. 2).

In the studied streams in the Paraguay basin all the analyzed community parameters showed significant differences between the sub-basins (Table 1 and Fig. 3). For the Paraná basin richness and evenness showed significant differences only among the sub-basins. However, the number of individuals differed seasonally (Table 1 and Fig. 4). Significant interaction between the sub-basins and months were encountered in number of individuals collected and evenness in Paraguay basin and number of individuals collected for Paraná basin.

Of the nine environmental variables assessed, only four (altitude, water temperature, stream width and depth) showed significant influence on community parameters analyzed. Species richness was significantly explained by the altitude in Paraná basin and by the stream width in Paraguay basin. The number of individuals collected was explained by the water temperature in Paraná basin and by water temperature and altitude in Paraguay basin. The evenness was not explained by selected variables data set in Paraná river basin; however, evenness was significantly explained by the stream depth and width in Paraguay basin (Table 2).

The results from the multiple linear regression allowed us to conclude that in Paraguay basin; streams of higher volume had larger species richness, whereas in the Paraná basin, streams located in low altitudes showed higher species richness. Increase in the water temperature led to an increase the number of individuals collected. For the Paraguay basin, wider and shallower streams showed higher values of evenness. 


\section{DISCUSSION}

Despite the geographic proximity, the two basins differ sharply in relief: The Paraguay basin has steeper slopes, mainly in Apa and Miranda subbasins. These slopes isolate some of the streams in these sub-basins from the other areas, so that their fishes species are those that persist through the formation of Pantanal floodplain or else have high dispersion ability, and are able to pass the countless waterfalls in these streams. However, the low species richness found in Apa and Miranda sub-basins, besides being responsible for the smallest species richness and evenness among the Paraguay sub-basins, also influenced the comparison between Paraguay and Paraná basins. The lower species richness in Paraguay basin streams did not occur in accordance with the jackknife procedure, demonstrating higher beta diversity in the fishes communities in Paraguay basin streams.
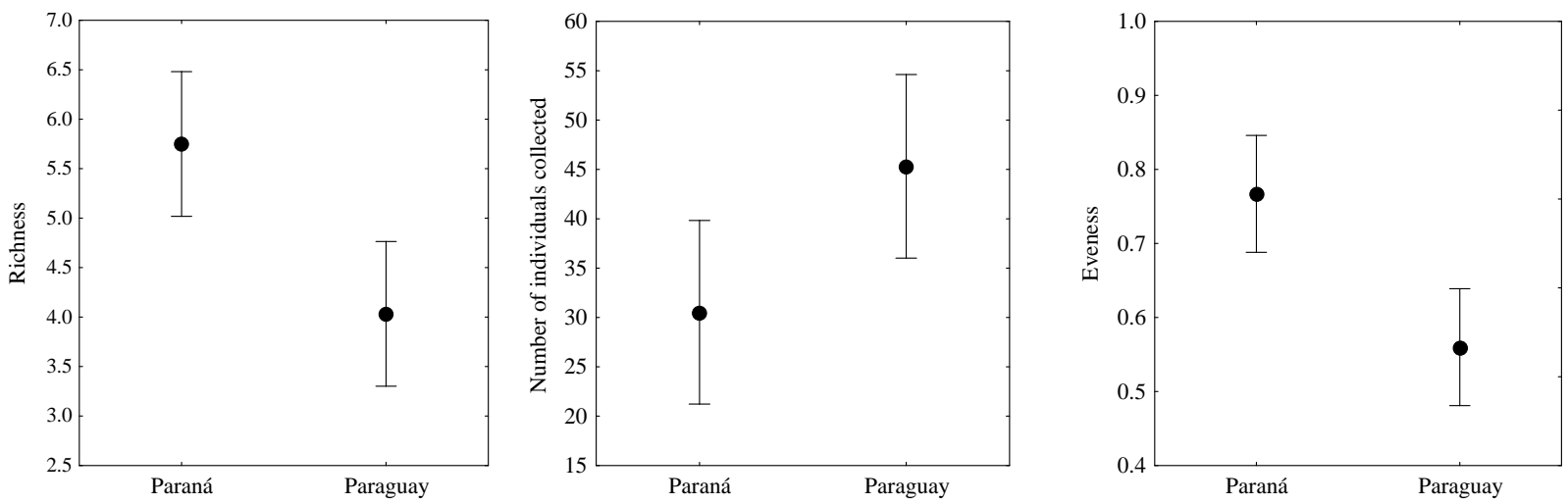

Figure 2 - Mean values and confidence intervals for species richness, number of individuals collected and evenness between the analyzed basins

Table 1 - Results of analysis of variance (ANOVA) for fish communities in streams of the Paraguay and Paraná basins.

\begin{tabular}{|c|c|c|c|c|c|}
\hline Basin & Response Var. & Explanatory Var. & $\mathbf{r}^{2}$ & $\mathbf{F}$ & $\mathbf{P}$ \\
\hline \multirow{9}{*}{ Paraguay } & \multirow{3}{*}{ Richness } & Months & 0.089 & 1.051 & 0.398 \\
\hline & & Sub-Basin & 0.379 & 11.369 & 0.000 \\
\hline & & Months*Sub-basin & 0.000 & 0.016 & 0.901 \\
\hline & \multirow{3}{*}{ Individuals } & Months & 0.140 & 1.753 & 0.138 \\
\hline & & Sub-Basin & 0.327 & 9.076 & 0.000 \\
\hline & & Months*Sub-basin & 0.145 & 9.829 & 0.003 \\
\hline & \multirow{3}{*}{ Evenness } & Meses & 0.023 & 0.252 & 0.937 \\
\hline & & Sub-Basin & 0.550 & 22.803 & 0.000 \\
\hline & & Months*Sub-basin & 0.071 & 4.460 & 0.039 \\
\hline \multirow{9}{*}{ Paraná } & \multirow{3}{*}{ Richness } & Months & 0.177 & 2.330 & 0.055 \\
\hline & & Sub-Basin & 0.210 & 4.957 & 0.004 \\
\hline & & Months*Sub-basin & 0.005 & 0.269 & 0.606 \\
\hline & \multirow{3}{*}{ Individuals } & Months & 0.307 & 4.794 & 0.001 \\
\hline & & Sub-Basin & 0.070 & 1.404 & 0.251 \\
\hline & & Months* Sub-basin & 0.109 & 7.060 & 0.010 \\
\hline & \multirow{3}{*}{ Evenness } & Months & 0.146 & 1.850 & 0.119 \\
\hline & & Sub-Basin & 0.139 & 3.013 & 0.038 \\
\hline & & Months*Sub-basin & 0.058 & 3.560 & 0.064 \\
\hline
\end{tabular}


Although the sample size (number of individuals) was one the main determinants of species richness (Fisher et al., 1943; Melo et al., 2003) the results for Paraguay basin did not corroborate this presupposition, because the Apa and Miranda subbasins were the ones that showed a higher number of individuals and lower species richness.

From the differences in the diversity and fishes abundance among the Paraguay sub-basins, higher richness and evenness seemed to be associated with the dispersal capacity of species in these communities, because the low mean altitude associated with the lack of higher waterfalls in the Apa and Miranda sub-basins, would facilitate species dispersal from the lower part of the basin. Poff (1997) proposed the existence of selective forces in the environment that acted as a filter, selecting those species with traits that allowed a certain habitat to be occupied. Martin-Smith (1998) studying the fishes communities in Malayan streams observed that rifle communities are more similar in the species composition, suggesting that hydrological characteristics were selected from the regional species pool, a smaller number of species occurred in these habitats. Considering waterfalls as barrier to fishes migration, these data corroborated this hypothesis, because only species with high dispersal capacity and adaptive plasticity persist in small streams at high altitudes, which environmentally less stable.

For Paraná basin, the differences among subbasins were smaller (Table 1 and Fig. 3), which could be the result of greater geological homogeneity among these sub-basins, which lacked waterfalls barriers like those in the Paraguay basin, and probably also because the sub-basins belonged to the same basin (Ivinhema), which include most tributaries of the Paraná in the state of Mato Grosso do Sul. In the Paraguay basin, only the Nioaque and Miranda rivers arise before they enter the Paraguay River. Therefore, the present results suggested that local (hydrology) and regional (sub-basins differentiation) factors interacted to determine the stream fishes diversity and abundance. This corroborate the interpretations of Belliard et al., (1997) and Matthews and Robison (1998).

Vendel et al., (2002) studying fishes communities in the Brazilian tidal creeks, did not encounter seasonal variation, suggesting that occupation patterns were more important than seasonal variation in fishes community organization. Súarez and Petrere (2003) analyzing the patterns of icthyofauna spatial distribution in Iguatemi River, a tributary of the Paraná River, observed that hydrological differences between studied habitats they were among the main determinant of species distribution, and the streams located at higher altitudes differed significantly from the streams of low altitude sites. We found that in the Paraguay basin, species richness and evenness were more influenced by the biogeographic events (subbasins isolament), interacting to greater ease of colonization and habitat availability in the streams of the Nioaque and Aquidauana sub-basins, which situated at the lower altitudes and had larger volumes. On the other hand, for the Paraná basin, the significant importance only of altitude, together with the ANOVA results, suggested that the interaction between habitat features and seasonal variation in diversity were important in structuring these stream fish communities.

Súarez and Petrere (2003) demonstrated the minor importance of seasonal variation in co-occurrence patterns in the Iguatemi basin, suggesting that this was a result of reproductive migration by the species that lived in the lakes along the streams studied. In the present study, were more individuals obtained in hotter and rainier periods, and many of these species were sexually mature (personal observation). It is probable that this variation was a result of the reproductive migration, which explained the significant influence of the water temperature on the number of individuals collected. Similarly, the species encountered in the streams of the Paraguay basin (Apa and Miranda sub-basins), as a result of biogeographic barriers, were those which that completed their entire life cycle in these streams, with no extensive reproductive migration. 

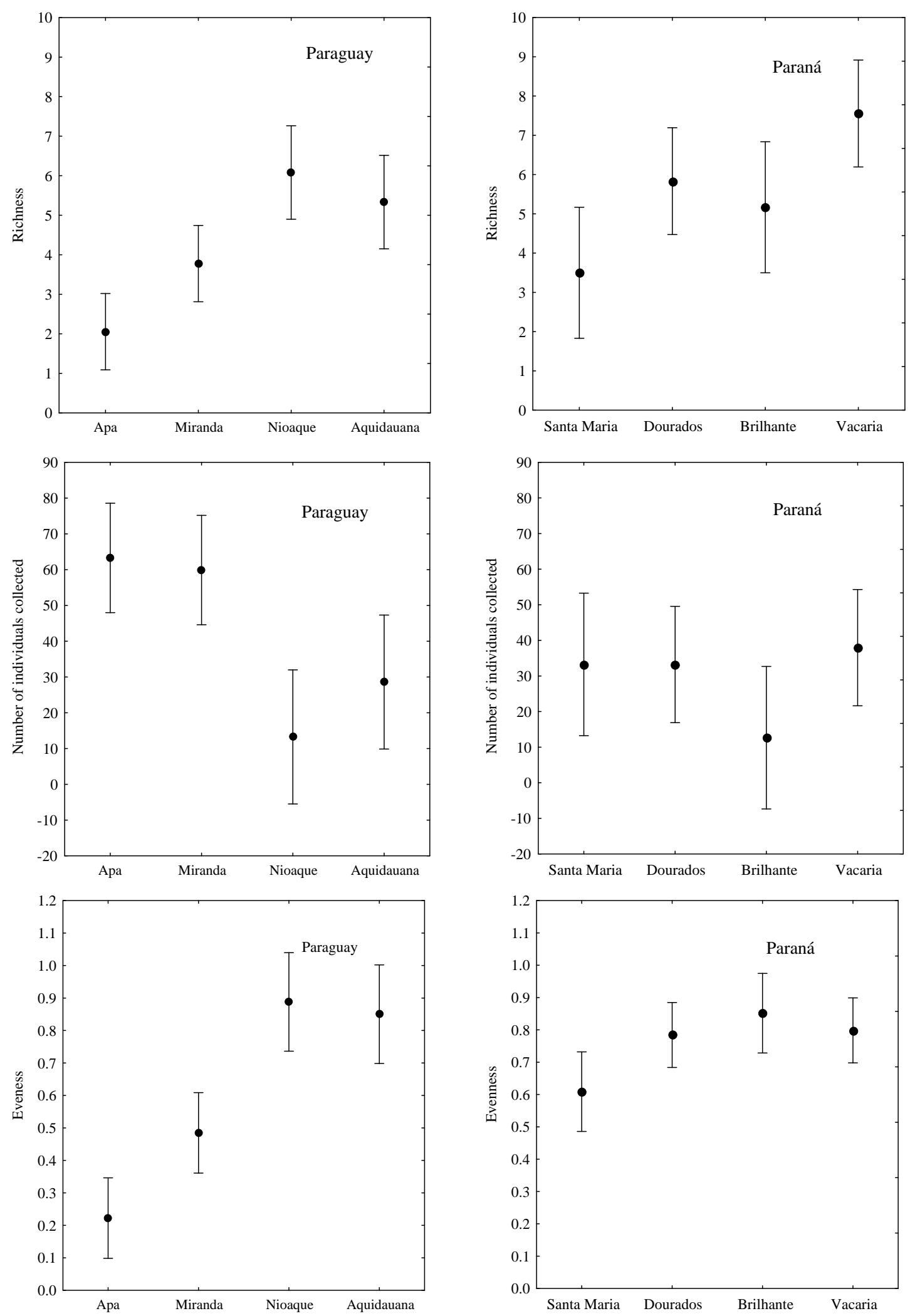

Figure 3 - Spatial variation in mean values and confidence intervals for richness, number of individuals collected and evenness for studied streams 

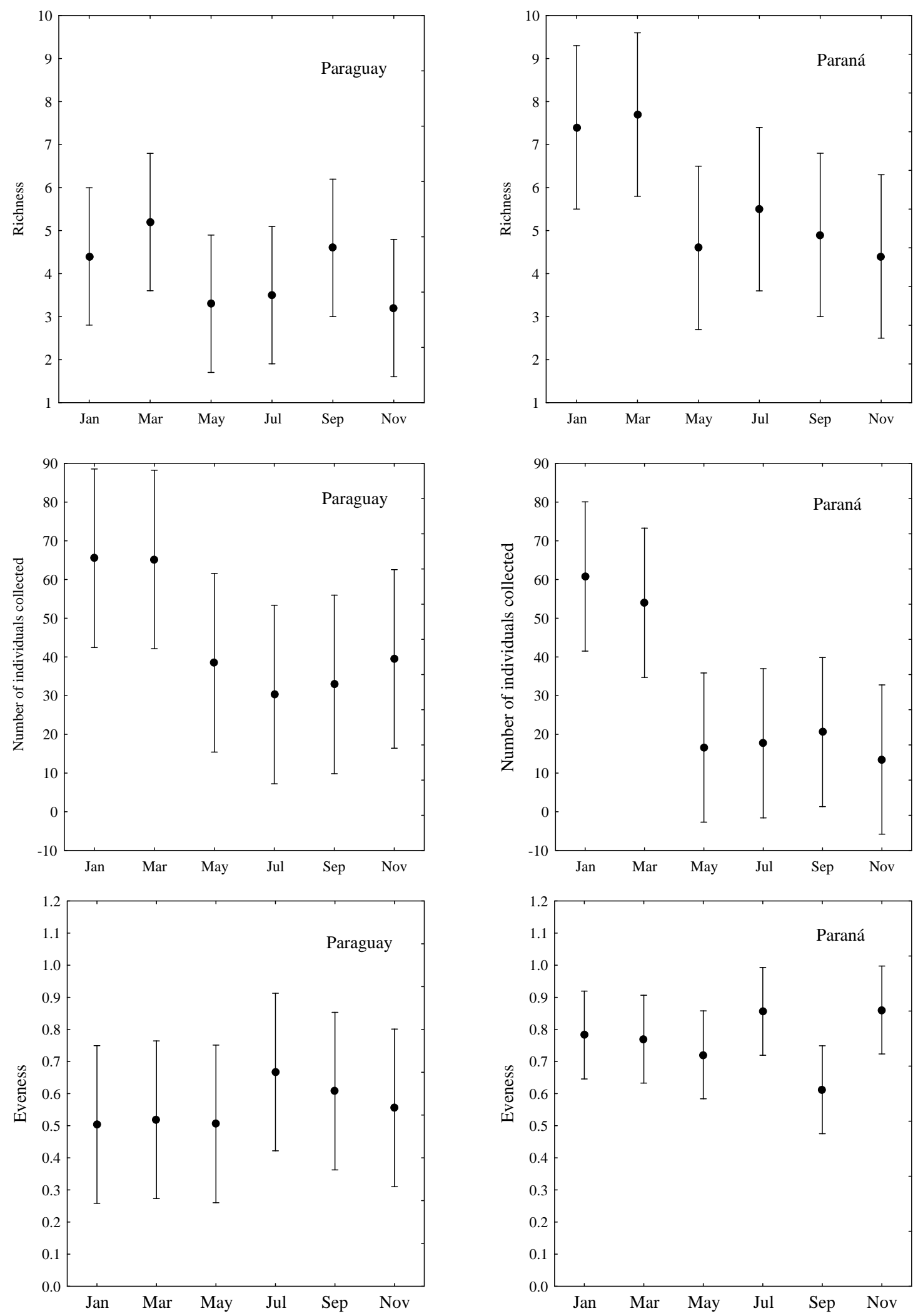

Figure 4 - Monthly mean values and confidence intervals for richness, number of individuals collected and evenness for studied streams 
Table 2 - Results of the linear multiple regressions between species richness, number of individuals collected, evenness and environmental characteristics for streams of Paraguay and Paraná basin-MS.

\begin{tabular}{|c|c|c|c|c|c|c|}
\hline \multirow{2}{*}{$\begin{array}{l}\text { Analyzed } \\
\text { Variables }\end{array}$} & \multicolumn{2}{|c|}{ Species richness } & \multicolumn{2}{|c|}{$\begin{array}{c}\text { Number of individuals } \\
\text { collected }\end{array}$} & \multicolumn{2}{|c|}{ Evenness } \\
\hline & Paraná & Paraguay & Paraná & Paraguay & Paraná & Paraguay \\
\hline Turbidity & $-0.059 \mathrm{~ns}$ & $0.034 \mathrm{~ns}$ & $-0.317 \mathrm{~ns}$ & $-0.016 \mathrm{~ns}$ & $0.002 \mathrm{~ns}$ & $0.002 \mathrm{~ns}$ \\
\hline $\mathrm{pH}$ & $-0.857 \mathrm{~ns}$ & $0.481 \mathrm{~ns}$ & $-19.208 *$ & $-2.322 \mathrm{~ns}$ & $-0.025 \mathrm{~ns}$ & $0.067 \mathrm{~ns}$ \\
\hline Conductivity & $30.649 \mathrm{~ns}$ & $-9.186 \mathrm{~ns}$ & $240.878 \mathrm{~ns}$ & $37.081 \mathrm{~ns}$ & $-1.186 \mathrm{~ns}$ & $-0.779 \mathrm{~ns}$ \\
\hline Dissolved oxygen & $0.019 \mathrm{~ns}$ & $-0.018 \mathrm{~ns}$ & $0.114 \mathrm{~ns}$ & $-0.037 \mathrm{~ns}$ & $0.004 \mathrm{~ns}$ & $0.000 \mathrm{~ns}$ \\
\hline Altitude & $-0.012 *$ & $-0.007 \mathrm{~ns}$ & $0.008 \mathrm{~ns}$ & $\mathbf{0 . 1 8 8} * *$ & $0.000 \mathrm{~ns}$ & $-0.001 \mathrm{~ns}$ \\
\hline Water temp. & $0.194 \mathrm{~ns}$ & $0.153 \mathrm{~ns}$ & $2.713 *$ & $2.703 * *$ & $0.004 \mathrm{~ns}$ & $-0.005 \mathrm{~ns}$ \\
\hline Stream width & $0.289 \mathrm{~ns}$ & $\mathbf{0 . 6 2 0} * *$ & $3.932 \mathrm{~ns}$ & $-3.776 \mathrm{~ns}$ & $-0.029 \mathrm{~ns}$ & $0.144 * * *$ \\
\hline Stream depth & $-0.253 \mathrm{~ns}$ & $-3.338 \mathrm{~ns}$ & $24.018 \mathrm{~ns}$ & $16.789 \mathrm{~ns}$ & $-0.025 \mathrm{~ns}$ & $\mathbf{- 0 . 7 4 0} * *$ \\
\hline Water velocity & $-0.812 \mathrm{~ns}$ & $-0.216 \mathrm{~ns}$ & $-8.839 \mathrm{~ns}$ & $-17.593 \mathrm{~ns}$ & $0.084 \mathrm{~ns}$ & $0.060 \mathrm{~ns}$ \\
\hline $\begin{array}{l}\text { Statistical } \\
\text { summary }\end{array}$ & $\begin{aligned} \mathrm{r}^{2} & =0.415 \\
\mathrm{~F} & =3.938 * * *\end{aligned}$ & $\begin{array}{c}\mathrm{R}^{2}=0.478 \\
\mathrm{~F}=5.079 * * *\end{array}$ & $\begin{array}{c}\mathrm{r}^{2}=0.432 ; \\
\mathrm{F}=4.226 * *\end{array}$ & $\begin{array}{c}\mathrm{r}^{2}=0.629 ; \\
\mathrm{F}=9.421 * * *\end{array}$ & $\begin{array}{c}\mathrm{r}^{2}=0.170 \\
\mathrm{~F}=1.136 \mathrm{~ns}\end{array}$ & $\begin{array}{c}\mathrm{r}^{2}=0.652 \\
\mathrm{~F}=10.429 * * *\end{array}$ \\
\hline
\end{tabular}

Townsend (1989) proposed that when the lotic habits suffered periodic hydrological disturbances, the communities would be composed by efficient settlers, and in these circumstances the competition was not a strong community determinant. Peres-Neto (2004) concluded that fishes communities in the Maracú basin were determined mainly by the selective species/habitat preferences and that biotic interactions did not play an important role in community organization. For Upper Paraná basin, Pavanelli and Caramaschi (2003) observed seasonal variations in the fishes species composition, as a result of migration between the streams and the Paraná River, corroborating the importance of migration in determining fishes community structure.

Taylor and Warren (2001) suggested that highervolume streams normally have low environmental variability and a higher migration rate. The streams of the Paraguay basin have lower mean flow than the streams of the Paraná basin (Paraná=1.44 and Paraguay $=0.67 \mathrm{~m}^{3} / \mathrm{s}$ ) which, together with the lack of barriers to dispersal, suggested that migration was more important for the organization of the stream fishes communities, as suggested by Peres-Neto (2004) and Pavanelli and Caramaschi (2003).

\section{RESUMO}

Examinamos a influência da variação espacial, temporal e das variáveis ambientais sobre as comunidades de peixes em riachos de cabeceira das bacias dos rios Paraguai e Paraná (Brasil).
4.605 indivíduos foram amostrados, distribuídos em 60 espécies. Os riachos da bacia do rio Paraná apresentaram maior riqueza total de espécies (42) que os riachos da bacia do rio Paraguai (40), no entanto, a riqueza estimada foi maior na bacia do rio Paraguai (53) que nos da bacia do rio Paraná (50). Os riachos da bacia do rio Paraná apresentaram maiores valores médios de riqueza e equitabilidade, contudo, maiores valores médios de número de indivíduos foram obtidos na bacia do rio Paraguai. Encontramos diferenças significativas entre as sub-bacias do rio Paraguai assim como do rio Paraná para a riqueza de espécies e equitabilidade, contudo, nesta última o número de indivíduos variou apenas sazonalmente. As variáveis ambientais mais importantes na determinação da diversidade e abundancia das espécies foram altitude, temperatura da água, largura e profundidade dos riachos para as duas bacias.

\section{ACKNOWLEDGEMENTS}

The authors thank FUNDECT (Process: 489/02) and UEMS for the financial support and Flávio C. T. Lima (MZUSP-São Paulo) for taxonomic help.

\section{REFERENCES}

Angermeier, P. L. and Winston, M. R. (1998) Local vs. Regional influences on local diversity in stream fish communities of Virginia. Ecology 79, 911-927. 
Bain, M. B., Finn, T. and Booke, H. E. (1988) Stream flow regulation and fish community structure. Ecology 69, 382-392.

Barretto, M. G. and Uieda,V. S. (1998) Influence of the abiotic factors on the ichthyofauna composition in different orders streches of Capivara River, São Paulo State, Brazil. Verh. Internat. Verein. Limnol. 26, 21802183.

Belliard, J., Boët, P. and Tales, E. (1997) Regional and longitudinal patterns of fish community structure in the Seine River basin, France. Environmental Biology of Fishes 50, 133-147.

Britski, H. A., Silimon K. Z. de S. and Lopes, B. S. (1999) Peixes do Pantanal, Manual de identificação. Brasília: Embrapa - SPI, Corumbá: Embrapa - CPAP. 184pp.

Deus, C. P. and Petrere-Junior, M. (2003) Seasonal diet shifts of seven fish species in an atlantic rainforest stream in southeastern Brazil. Brazilian Journal of Biology 63, 579-588.

Fisher,R. A., Corbet, A. S. and Williams, C.B. (1943) The relation between the number of species and the number of individuals in a random sample of an animal population. Journal of Animal Ecology 12, 42-58.

Godoi-Filho, J. D. (1986) Aspectos geológicos do Pantanal Mato-Grossense e de sua área de influência. In: Simpósio sobre Recursos Naturais e SócioEconômicos do Pantanal, 1, Corumbá. Anais... Brasília, p. 63-76.

Grenouillet, G., Pont, D. and Seip, K. L. (2002) Abundance and species richness as a function of food resources and vegetation structure: juvenile fish assemblages in rivers. Ecography 25, 641-650.

Heltshe, J. F. and Forrester, N. E. (1983) The jackknife estimate of species richness. Biometrics 39, 1-11.

Jackson, D. A., Peres-Neto, P. R. and Olden, J. D. (2001) What controls who is where in freshwater fish communities - the roles of biotic, abiotic, and spatial factors. Canadian Journal of Fisheries and Aquatic Sciences 58, 157-170.

Lamouroux, N., Poff, N. L. and Angermeier, P. L. (2002) Intercontinental convergence of stream fish community traits along geomorphic and hydraulic gradient. Ecology 83, 1792-1807.

Ludwig, J. A. and Reynolds, J. F. (1988) Statistical Ecology. A Primer on methods and computing. A Wiley-Intercience Publication JOHN WILER and SONS. U.S.A. 338 p.

Martin-Smith, K. M. (1998) Relationships between fishes and habitat in rainforest streams in Sabah, Malaysia. Journal of Fish Biology 52, 458-482.

Matthews, W. J. and Robison, H. W. (1998) Influence of drainage connectivity, drainage area and regional species richness on fishes of the interior highlands in Arkansas. The American Midland Naturalist 139, 1930 .
McGarigal, K., Cushman, S. and Stafford, S. (2000). Multivariate Statistics for Wildlife and Ecology Research. Springer-Verlag. New York, 283p.

Melo, A. S., Pereira, R. A. S., Santos, A. J., Shepherd, G. J., Machado, G., Medeiros, H. F. and Sawaya, R. J. (2003) Comparing species richness among assemblages using sample units: why not use extrapolation methods to standardize different sample sizes? Oikos 101, 398-410.

Mérigoux, S., Dolédec, S. and Statzner, B. (2001) Species traits in relation to habitat variability and state: neotropical juvenile fish in Floodplain creeks. Freshwater Biology 46, 1251-1267.

Oberdorff, T., Hugueny, B. and Vigneron, T. (2001) Is assemblage variability related to environmental variability? An answer for riverine fish. Oikos 93, 419-428.

Pavanelli, C. S. and Caramaschi, E. P. (2003) Temporal and spatial distribution of the ichthyofauna in two streams of the upper Rio Paraná Basin. Brazilian Archives of Biology and Technology 46, 271-280.

Peres-Neto, P. R. (2004) Patterns in the co-occurrence of fish species in streams: the role of site suitability, morphology and phylogeny versus species interactions. Oecologia 140, 352-360.

Poff, N. L. (1997). Landscape filters and species traits: towards mechanistic understanding and prediction in stream ecology. Journal of the North American Benthological Society 16: 391-409.

Poff, N. L. and Allan, J. D. (1995) Functional organization of stream fish assemblages in relation to hydrological variability. Ecology 76, 606-627.

Resh, V. H., Brown, A. V., Covich, A. P. Gurtz, M. E., Li, H. W., Minhall, G. W., Reice, S. R., Sheldon, A. L. Wallace, J. B. and Wissmar, R. (1988) The role of disturbance in stream ecology. Journal of the North American Benthological Society 7, 433-455.

Súarez, Y. R. and Petrere-Júnior, M. (2003) Associações de espécies de peixes em ambientes lóticos da bacia do rio Iguatemi, Estado do Mato Grosso do Sul. Acta Scientiarum 25, 361-367.

Taylor, C. M. (2000) A large-scale comparative analysis of riffle and pool fish communities in an upland stream system. Environmental Biology of Fishes 58, 89-95.

Taylor, C. M. and Warren, Jr, M. L. (2001) Dynamics in species composition of stream fish assemblages: environmental variability and nested subsets. Ecology 82, 2320-2330.

Tonn, W. M., Magnuson, J. J., Rask, M. and Toivonen, J. (1990) Intercontinental comparison of small-lake fish assemblages: The balance between local and regional processes. American Naturalist 136, 345375.

Townsend, C. R. (1989) The patch dynamics concept of stream community ecology. Journal of the North American Benthological Society 8, 36-50. 
Vendel, A. L., Spach, H. L., Lopes, S. G. and Santos, C. (2002) Structure and dynamics of fish assemblages in a tidal creek environment. Brazilian Archives of Biology and Technology 45, 365-373.

Zaret, T. M. and Rand, A. S. (1971) Competition in tropical stream fishes: support for the competitive exclusion principle. Ecology 52, 336-342.

Received: October 17, 2005;

Revised: July 27, 2006;

Accepted: March 29 17, 2007. 